\title{
Atopic dermatitis and ascariasis in children aged 2 to 10 years
}

\author{
Maria Teresa Nascimento Silva, ${ }^{1}$ Valdenia M. Souza, ${ }^{2}$ Gerson Bragagnoli, ${ }^{3}$ \\ Teobaldo G. R. Pereira, ${ }^{4}$ Elizabeth Malagueño ${ }^{2}$
}

\begin{abstract}
Objective: To assess the association between atopic dermatitis (AD) and ascariasis in 2 to 10 -aged children from the neighborhood Pedregal, in the city of Campina Grande, Brazil, an area of low socioeconomic index.

Methods: Cross-sectional study conducted with the use of the standard questionnaire from the International Study of Asthma and Allergies in Childhood (ISAAC) and stool parasitological exam for Ascaris lumbricoides. The dependent variable was AD diagnosis: absent, mild, and severe. Multivariate logistic regression and descriptive analysis of the variable were used. Associations were estimated using relative risk (RR) and odds ratio (OR). The statistical inference was based on $95 \%$ confidence intervals $(95 \% \mathrm{CI})$.

Results: We assessed 1,195 children, $612(51.2 \%)$ female. The AD prevalence was $24.6 \%$, and ascariasis prevalence was $26.1 \%$. In the mild $A D$ group of children, $44(36.7 \%)$ were infected by $A$. lumbricoides, while in the severe $A D$ group, $40(22.9 \%)$ had the same geohelminthosis $(p=0.01)$. Comparing negative cases of $A D$ between mild and severe forms, the infection with $A$. lumbricoides increased the frequency of mild $A D(R R=1.7 ; p=0.009)$, but not the severe form $(R R=0.86 ; p=0.46)$. Evaluating only the positive cases of dermatitis, 120 mild $A D(40.8 \%)$ and 176 with severe $A D(58.2 \%)$, it can be said that the exposure to the parasite decreased the frequency of the severe form of dermatitis $(R R=1.46 ; p=0.016)$.

Conclusion: There is a high prevalence of $A D$ and of ascariasis in the population studied. The severe $A D$ is related to lower parasitemia of $A$. lumbricoides.
\end{abstract}

J Pediatr (Rio J). 2010;86(1):53-58: Atopic dermatitis, ascariasis, prevalence, children.

\section{Introduction}

Atopic dermatitis (AD), or atopic eczema, is an inflammatory disease that generally occurs in patients with family background of atopy. ${ }^{1}$ In industrialized countries, it is the most frequent inflammatory dermatosis in children. ${ }^{2}$ Genetic patterns, breastfeeding period, environment allergens, early use of antibiotics, and even the decrease in size of families have been related to risk factors to $\mathrm{AD}^{3}$ On the other hand, viral, bacterial infections, or immunization with BCG help to explain TH1-TH2 dicotomy. 4

$A D$ prevalence in Brazil is studied using the International Study of Asthma and Allergies in Childhood (ISAAC) standard questionnaire. ${ }^{5}$ In children from Manaus, Natal, Salvador, São Paulo, and Itajaí, Brazil, the prevalence of mild eczema varied between 8.6 and $13.1 \%$, while that of severe eczema, in those same places, was of 3.4 to $8.5 \%{ }^{6}$

1. Professora adjunta, Unidade Acadêmica de Medicina, Universidade Federal de Campina Grande (UFCG), Campina Grande, PB, Brazil.

2. Professora adjunta, Programa de Pós-Graduação em Medicina Tropical, Universidade Federal de Pernambuco (UFPE), Recife, PE, Brazil.

3. Professor adjunto, Unidade Acadêmica de Medicina, UFCG, Campina Grande, PB, Brazil.

4. Professor associado, Unidade Acadêmica de Medicina, UFCG, Campina Grande, PB, Brazil.

This article is related to the Post-Graduation Program in Tropical Medicine of the Universidade Federal de Pernambuco (UFPE), Recife, PE, Brazil, and to the Universidade Federal de Campina Grande (UFCG), Campina Grande, PB, Brazil.

Financial support: Coordenação de Aperfeiçoamento de Pessoal de Nível Superior (CAPES) and Universidade Federal de Campina Grande (UFCG), Campina Grande, PB, Brazil.

No conflicts of interest declared concerning the publication of this article.

Suggested citation: Silva MT, Souza VM, Bragagnoli G, Pereira TG, Malagueño E. Atopic dermatitis and ascariasis in children aged 2 to 10 years. J Pediatr (Rio J). 2010;86(1):53-58.

Manuscript submitted Aug 26 2009, accepted for publication Oct 282009

doi:10.2223/JPED.1962 
As $A D$, helminthes-generated infection is very frequent in developing countries 7,8 and have been associated to allergic diseases. In Brazil, ascariasis is one of the most common parasitoses. ${ }^{9}$ In Campina Grande, Brazil, in a previous study in the same area, a prevalence of $56.3 \%$ of Ascaris lumbricoides was observed. ${ }^{10}$

The high prevalence of atopy in urban areas of developing countries was related to the reduction of the exposition to geo-helminths. ${ }^{11-13}$ Other studies, as that of Lynch et al. ${ }^{14}$ and that of Williams \& Flohr, ${ }^{15}$ observed a reduction of risk of sensitization to allergens in children infected by $A$. lumbricoides. In a previous study, in the Pedregal community, Campina Grande, the association of asthma and ascariasis was not observed. ${ }^{14}$ Leonardi-Bee et al., ${ }^{16}$ in a meta-analysis, associated the infection by $A$. lumbricoides to a significant increase of asthma risk. Medeiros et al. ${ }^{17}$ observed the association between asthma and Schistosoma mansoni.

Despite the high prevalence of $A D$ and ascariasis, no studies showing the association among these two pathologies were found in Brazil. In Campina Grande, in the neighborhood of Pedregal, a high frequency of allergic diseases, as well as enteroparasitoses, was observed, which motivated the study on the possible association between $\mathrm{AD}$ and ascariasis. ${ }^{18}$

\section{Methods}

The population studied was constituted of children with ages ranging from 2 to 10 years old living in the neighborhood of Pedregal, in the city of Campina Grande, Brazil. In this community there are 2,655 families registered by the Family Health Program (Programa de Saúde da Família, PSF), with approximately 1,600 children in the age group studied, according to data provided by the Municipal Secretary of Health. The neighborhood population is estimated in 10,706 inhabitants, and the children studied respond for $14.9 \%$ of all the inhabitants. ${ }^{19}$

The study started in January, 16th, 2007 and ended in November, 19th, 2007. The ISAAC standard questionnaire (eczema mode) was applied to the responsible people for the 1,582 children during the home visit, and a recipient for feces collection was handed over. In this occasion the clinical dermatologic exam of the children was also conducted and the requirements of the informed consent form filled. The parasitological exam was done in the Parasitology Laboratory, Academic Unit of Medicine of the Universidade Federal de Campina Grande (UFCG), Campina Grande, Brazil. Of the 1,582 children, 1,195 $(75.5 \%)$ continued the study, presenting fecal samples for the coproparasitological exam. Due to temporary closing of the PSF of Pedregal, which prevented the samples to be handed over, 387 children (24.5\%) were excluded.
Campina Grande is a city located $7^{\circ} 13^{\prime} 50^{\prime \prime}$ of latitude south, $35^{\circ} 52^{\prime} 52^{\prime \prime}$ of longitude west, 552 meters of altitude, where temperature variances between 15 to $30{ }^{\circ} \mathrm{C}$ and relative humidity of air around $82 \%$ (Instituto Nacional de Meteorologia, INMET) are observed; the city also has high pluviometric indexes ( $754 \mathrm{~mm}$ per year in 2007, and 866 mm until August, 2008, according to the Agência Executiva de Gestão das Águas do Estado da Paraíba, AESA). Children who live in the area use light clothes and present various dermatological problems, such as scabiosis, pityriasis versicolor, and molluscum contagiosum, a typical disease of hot countries.

The ISAAC questionnaire was applied to assess AD and its symptoms. According to its criteria, the 'eczema that appears and disappears in the last 12 months' is considered mild $A D$, and 'eczema, flexurial lesions in the last 12 months and night itching', severe AD. The cases were distributed in three groups: no $A D$, mild $A D$, and severe $A D$.

In the research on $A$. lumbricoides the methods of Ritchie and Kato-Katz were used. All children with ascariasis were treated with mebendazol (100 mg, twice a day during 3 days), and those who had other enteral parasitoses were medicated according to indication.

The analytic procedures included univariate and multivariate descriptive analysis of logistic regression. In the multivariate analysis all the variables that presented value of $p<0.2$ were introduced in the logistic regression model, in association with $A D$, remaining in the model all that presented value of $p<0.05$. The associations were estimated by relative risk (RR) and odds ratio (OR), and statistic inferences were based on $95 \%$ confidence intervals (95\%CI).

The dependent variable was the diagnosis of absent $A D$, mild $A D$, and severe AD. The covariables were age, gender, family income, mother's degree of instruction, family background of allergy, and presence of $A$. lumbricoidesgenerated infection. Age, a continuous variable, was categorized in four groups: 2-3 years old, 4-5 years old, 6-7 years old, and 8-10 years old. In relation to family income, the sample was divided in 3 groups: < 1 minimum wage, 1-2 minimum wages and $\geq 2$ minimum wages. The variable 'mother's degree of instruction' was assessed in two groups: 1) illiterate mothers or who have not completed primary education, and 2) mothers who have completed primary education and of more instruction. The softwares Statistical Package for Social Sciences (SPSS) 10.0, Windows version, and STAT 9.2 were used in the analyses.

The research project was approved by the Research Ethics Committee on Human Beings of the Hospital Universitário Alcides Carneiro, (UFCG), Campina Grande (May 22, 2006). 


\section{Results}

In the demographic variables analysis of the 1,195 children studied, $51.2 \%(n=612)$ were female, with no difference in proportions according to sex observed. In relation to age, the average was 5.58 years, with standard deviation 2.58. The age group with the bigger number of children was $8-10$ years (28.3\%). Family income lower than or equal to one minimum wage was found in $91.1 \%$ of the families. And in the variable 'instruction', most of the mothers (68.4\%) had not completed primary education.

The prevalence of ascariasis was $26.1 \%(n=312)$, and that of AD was $24.7 \%(n=296)$. From these cases, $40.5 \%$ had mild $A D$, and $59.4 \%$, severe $A D$.

In the $A D$ cases, there was no difference between male and female $(p=0.258)$, neither association with age $(p=0.205)$. For family income analysis, we included the groups that received one to two minimum wages and $>$ than two minimum wages, excluding the group that received less than one minimum wage because it had no difference from the group with income of one to two minimum wages. A statistically significant relation between family income and $A D(p=0.022)$ was seen. The lowest income was seen as a protection factor for mild $A D(R R=0.42 ; 95 \% C I 0.23$ -
$0.78)$ and severe $A D(R R=0.52 ; 95 \% C I 0.30-0.91)$. In the analysis of mother's degree of instruction, there was no statistically significant difference between the studied groups $(\mathrm{RR}=0.71 ; 95 \% \mathrm{CI} 0.42-1.20 ; \mathrm{p}=0.16)$ (Table 1$)$.

Still in Table 1, if we analyze the presence of ascariasis, it was observed that there is an association with $A D$ $(p=0.016)$. Comparing negative cases of AD with mild and severe $A D$ cases, the presence of $A$. lumbricoides-generated infection increased the occurrence of mild $A D(R R=1.7$; $p=0.009)$, but not of severe $A D(R R=0.86 p=0.46)$.

If we assess only positive mild $A D$ cases ( $n=120$; $40.8 \%)$ and severe $A D(n=176)$, it is possible to see that the exposition to the parasite decreases the occurrence of the severe form $(R R=1.46 ; p=0.016)$.

In Table 2, the family background of allergic diseases such as asthma, rhinitis, urticaria, and $A D$ in mother and brothers is observed. The presence of severe AD in children was more common when the mother had rhinitis $(R R=1.62$; $p=0.02)$ or $A D(R R=2.69 ; p=0.085)$ and when the brothers have $A D(R R=6.16(p=0.001)$.

In the multivariate logistic regression analysis comprising family factors and the presence of $A$. lumbricoides, to observe the association of them with $A D$ and its mild and

Table 1 - Univariate analysis of the association between atopic dermatitis with demographic variables and ascariasis in children 2-10 years old in the neighborhood of Pedregal, Campina Grande, Brazil

\begin{tabular}{|c|c|c|c|c|c|c|c|}
\hline \multirow[b]{2}{*}{ Variables } & \multicolumn{3}{|c|}{ Dermatitis } & \multirow{2}{*}{$\begin{array}{c}\text { RR (95\%CI) } \\
\text { "No" vs. } \\
\text { "mild AD" }\end{array}$} & \multirow{2}{*}{\multicolumn{2}{|c|}{$\begin{array}{c}\text { RR (95\%CI) } \\
\text { "No" vs. } \\
\text { "severe AD" }\end{array}$}} & \multirow[b]{2}{*}{$\mathbf{p}$} \\
\hline & $\begin{array}{c}\text { No } \\
\text { n (\%) }\end{array}$ & $\begin{array}{c}\text { Mild } \\
\text { n (\%) }\end{array}$ & $\begin{array}{l}\text { Severe } \\
\text { n (\%) }\end{array}$ & & & & \\
\hline \multicolumn{8}{|l|}{$\operatorname{Sex}(p=0.258)$} \\
\hline Female & $466(51.8)$ & $53(44.2)$ & $93(52.8)$ & - & - & - & - \\
\hline Male & $433(48.2)$ & $67(55.8)$ & $83(47.2)$ & $1.36(0.92-1.99)$ & 0.115 & $0.96(0.69-1.32)$ & 0.807 \\
\hline \multicolumn{8}{|l|}{ Age group $(p=0.205)$} \\
\hline $2-3$ years & $252(28.0)$ & $30(25.0)$ & $50(28.4)$ & - & - & - & - \\
\hline $4-5$ years & $215(24.0)$ & $25(20.8)$ & $48(27.3)$ & $0.97(0.55-1.71)$ & 0.934 & $1.12(0.72-1.74)$ & 0.596 \\
\hline $6-7$ years & $189(21.0)$ & $21(17.5)$ & $26(14.8)$ & $0,96(0.72-1.30)$ & 0.818 & $0.83(0.64-1.07)$ & 0.159 \\
\hline $8-10$ years & $243(27.0)$ & $44(36.7)$ & $52(29.5)$ & $1.15(0.97-1.35)$ & 0.098 & $1.02(0.89-1.18)$ & 0.728 \\
\hline \multicolumn{8}{|c|}{ Family income $(p=0.022)$} \\
\hline$<1 \mathrm{MW}$ & $67(7.4)$ & $17(14.2)$ & $21(11.9)$ & - & - & - & - \\
\hline $1-<2 \mathrm{MW}$ & $426(47.4)$ & $46(38.3)$ & $70(39.8)$ & $0.42(0.23-0.78)$ & 0.006 & $0.52(0.30-0.91)$ & 0.022 \\
\hline$\geq 2 \mathrm{MW}$ & $406(45.2)$ & $57(47.5)$ & $85(48.3)$ & $0.89(0.67-1.20)$ & 0.481 & $0.97(0.75-1.24)$ & 0.789 \\
\hline \multicolumn{8}{|l|}{ Instruction $(p=0.197)$} \\
\hline education incomplete & $720(80.1)$ & $102(84.7)$ & $149(85.0)$ & - & - & - & - \\
\hline $\begin{array}{l}\text { Primary education } \\
\text { complete or more }\end{array}$ & $179(19.9)$ & $18(15.3)$ & $27(15.0)$ & $0.71(0.42-1.20)$ & 0.203 & $0.73(0.47-1.13)$ & 0.160 \\
\hline \multicolumn{8}{|c|}{ Ascaris lumbricoides $(p=0.016)$} \\
\hline Presence & $228(25.4)$ & $44(36.7)$ & $40(22.7)$ & 1.0 & - & 1.0 & - \\
\hline Absence & $671(74.6)$ & $76(63.3)$ & $136(77.3)$ & $1.70(1.14-2.54)$ & 0.009 & $0.86(0.59-1.26)$ & 0.460 \\
\hline
\end{tabular}


Table 2 - Multivariate analysis of association of atopic dermatitis with family background for allergy in children with ages ranging from 2 to 10 years in the neighborhood of Pedregal, Campina Grande, Brazil

\begin{tabular}{|c|c|c|c|c|c|c|c|}
\hline \multirow[b]{2}{*}{ Variables } & \multicolumn{3}{|c|}{ Dermatitis } & \multirow{2}{*}{$\begin{array}{c}\text { RR (95\%CI) } \\
\text { "No" vs. } \\
\text { "mild AD" }\end{array}$} & \multirow{2}{*}{\multicolumn{2}{|c|}{$\begin{array}{c}\text { RR (95\%CI) } \\
\text { "No" vs. } \\
\text { "severe AD" }\end{array}$}} & \multirow[b]{2}{*}{$\mathbf{p}$} \\
\hline & $\begin{array}{c}\text { No } \\
\text { n (\%) }\end{array}$ & $\begin{array}{c}\text { Mild } \\
\text { n (\%) }\end{array}$ & $\begin{array}{c}\text { Severe } \\
\text { n (\%) }\end{array}$ & & & & \\
\hline \multicolumn{8}{|c|}{ Mother asthma $(p=0.298)$} \\
\hline No & $679(77.4)$ & $90(71.9)$ & $120(76.3)$ & 1.0 & - & 1.0 & - \\
\hline Yes & $198(22.6)$ & $28(28.1)$ & $47(23.7)$ & $1.06(0.67-1.68)$ & 0.779 & $1.34(0.92-1.94)$ & 0.121 \\
\hline \multicolumn{8}{|c|}{ Mother rhinitis $(p=0.020)$} \\
\hline No & $616(70.2)$ & $82(59.3)$ & $99(69.5)$ & 1.0 & - & 1.0 & - \\
\hline Yes & $261(29.8)$ & $36(40.6)$ & $68(30.5)$ & $1.03(0.68-1.57)$ & 0.868 & $1.62(1.15-2.28)$ & 0.005 \\
\hline \multicolumn{8}{|c|}{ Mother urticaria $(p=0.184)$} \\
\hline No & $885(97.7)$ & $115(95.2)$ & $159(97.5)$ & 1.0 & - & 1.0 & - \\
\hline Yes & $20(2.3)$ & $3(4.8)$ & $8(2.5)$ & $1.11(0.32-3.81)$ & 0.862 & $2.15(0.93-4.96)$ & 0.073 \\
\hline \multicolumn{8}{|c|}{ Mother AD $(p=0.085)$} \\
\hline No & $863(98.4)$ & $116(98.3)$ & $160(95.8)$ & 1.0 & - & 1.0 & - \\
\hline Yes & $14(1.6)$ & $02(1.7)$ & $7(4.2)$ & $1.06(0.23-4.73)$ & 0.936 & $2.69(1.07-6.78)$ & 0.035 \\
\hline \multicolumn{8}{|c|}{ Brother asthma $(p=0.678)$} \\
\hline No & $284(39.4)$ & $52(35.6)$ & $32(36.6)$ & 1.0 & - & 1.0 & - \\
\hline Yes & $437(60.6)$ & $58(64.4)$ & $90(63.4)$ & $1.17(0.74-1.85)$ & 0.482 & $1.12(0.77-1.63)$ & 0.536 \\
\hline \multicolumn{8}{|c|}{ Brother rhinitis $(p=0.274)$} \\
\hline No & $284(39.4)$ & $36(32.4)$ & $46(40.0)$ & 1.0 & - & 1.0 & - \\
\hline Yes & $436(60.6)$ & $54(67.6)$ & $96(60.0)$ & $1.09(0.73-1.62)$ & 0.665 & $1.18(0.85-1.64)$ & 0.317 \\
\hline \multicolumn{8}{|c|}{ Brother urticaria $(p=0.152)$} \\
\hline No & $673(93.3)$ & $84(88.7)$ & $126(93.3)$ & 1.0 & - & 1.0 & - \\
\hline Yes & $48(6.7)$ & $6(11.3)$ & $16(6.7)$ & $1.20(0,74-1.96)$ & 0.448 & $1.09(0.70-1.70)$ & 0.672 \\
\hline \multicolumn{8}{|c|}{ Brother AD $(p=0.001)$} \\
\hline No & $673(93.2)$ & $81(90.0)$ & $98(69.0)$ & 1.0 & - & 1.0 & - \\
\hline Yes & $49(6.8)$ & $09(10.0)$ & $44(31.0)$ & $1.52(0.72-3.22)$ & 0.268 & $6.16(3.89-9.75)$ & $<0.001$ \\
\hline
\end{tabular}

$95 \% \mathrm{Cl}=95 \%$ confidence interval; $\mathrm{AD}=$ atopic dermatitis; $\mathrm{RR}=$ relative risk.

severe forms (Table 3), one can observe that the presence of the parasite has a strong association with the mild form of $A D(O R=2.26 ; 95 \% C I 1.38-3.68 ; p<0.001)$. Having brothers with $A D$ increases significantly the risk of $A D$ in its severe form (OR $=5.995 \% \mathrm{CI} 3.63-6.69 ; \mathrm{p}<0.001)$, much more than maternal rhinitis $(\mathrm{OR}=1.55 ; 95 \% \mathrm{CI}$ 1.04-2.31; $p<0.028)$. Mother's $A D$ increases the risk of severe $A D$ in the children $(O R=3.15 ; 95 \% C I$ 0.98-10.1; $\mathrm{p}<0.053)$.

\section{Discussion}

The presence of $A D$ is a genetically predictive condition, moderated by environmental factors. ${ }^{20} \mathrm{AD}$ prevalence has been well studied after the recording of data obtained by the ISAAC questionnaire. ${ }^{5,6}$ The higher values were observed in urban centers in Africa, Australia, North and West Europe, and the lower values, in China, Eastern Europe and Asia.

In Brazil, ISAAC phase 3 showed significant differences in various assessed centers, with data varying in the item 'eczema' from 7.3 to $13.3 \%$ and, in 'flexures eczema', from 5.3 to $13.1 \%$ in children $6-7$ years old. ${ }^{6}$
The association between AD and ascariasis have been little studied, despite their being considered high prevalence pathologies in the whole world, both in developed and developing countries.7,8 This status was observed in this study, endorsed by low income and mother's low instruction degree.

Even if an instrument for the qualification of the precarious socioeconomic and hygiene and sanitary conditions have not been addressed, these conditions exist in the neighborhood of Pedregal and they favor the presence of geohelminths and other parasitoses. A. lumbricoides prevalence was lower than the one seen in a previous study $(56.3 \%),{ }^{21}$ possibly due to the prophylactic prescription of antihelminthic medication by the PSF professionals before the verification of the presence of parasites in coproparasitological exam.

The parasitary infection diagnosis in a cross-sectional study with single fecal material collection may indicate both a new infection and a chronic infection. The absence of infection may also indicate, presumably, non-exposition or a recent treatment.7,12

Climate may affect asthma and $A D$ prevalence in children. ${ }^{22}$ The prevalence found by Solé et al. ${ }^{23}$ in centers 
Table 3 - Multivariate analysis of the factors 'presence of Ascaris lumbricoides' and family background for allergy in atopic dermatitis in children from 2 to 10 years old in the neighborhood of Pedregal, Campina Grande, Brazil

\begin{tabular}{|c|c|c|c|c|}
\hline Variables & $\begin{array}{l}\text { Raw OR (95\%CI) } \\
\text { "No" vs. "mild AD" }\end{array}$ & $\mathbf{p}$ & $\begin{array}{l}\text { Adjusted OR (95\%CI) } \\
\text { "No" vs. "severe AD" }\end{array}$ & $\mathbf{p}$ \\
\hline \multicolumn{5}{|c|}{ Ascaris lumbricoides } \\
\hline Absence & 1,0 & - & - & - \\
\hline Presence & $2.26(1.38-3.68)$ & 0.001 & $1.02(0.63-1.64)$ & 0.917 \\
\hline \multicolumn{5}{|c|}{ Brother with $A D$} \\
\hline No & 1,0 & - & - & - \\
\hline Yes & $1.57(0.73-3.37)$ & 0.245 & $5.94(3.63-6.69)$ & $<0.001$ \\
\hline \multicolumn{5}{|c|}{ Mother with rhinitis } \\
\hline No & 1.0 & - & - & - \\
\hline Yes & $1.28(0.82-2.10)$ & 0.253 & $1.55(1.04-2.31)$ & 0.028 \\
\hline \multicolumn{5}{|c|}{ Mother with $A D$} \\
\hline No & 1.0 & - & - & - \\
\hline Yes & $1.79(0.36-8.82)$ & 0.46 & $3.15(0.98-10.1)$ & 0.053 \\
\hline
\end{tabular}

$95 \% \mathrm{Cl}=95 \%$ confidence interval $; \mathrm{AD}=$ atopic dermatitis; $\mathrm{RR}=$ relative risk.

near to the line of the Equator (Manaus, $12.0 \%$ in 'eczema' and $8.0 \%$ in 'flexures eczema'; and Natal, 13.1 e $13.0 \%$, respectively) show high prevalence, coinciding with this study. In a study conducted in Nigeria, where climatic conditions similar to Northeastern Brazilian ones are observed, Nnoruka et al. ${ }^{24}$ considered as aggravating factors of $A D$ the intolerance to heat, excessive transpiration and in-house humidity.

Atmospheric pollution would be an aggravating factor, as documented by Fernández-Mayoralas et al., ${ }^{25}$ a fact that was not observed in a study conducted in Brazil, in cities with a higher pollution level.23 In the neighborhood of Pedregal, home garbage burnings are frequent, and families that use firewood and coal in their kitchens are found, which are aggravating factors for allergic diseases.

The presence of $A$. lumbricoides in children in this study protected them of severe $A D$, possibly by immunological mechanisms. This same phenomenon was observed by Wordemann et al. in Cuban children. ${ }^{7}$ Dagoye et al. suggested that the reduction of parasitic infections may be a determining factor to the increase of allergic diseases in developed and developing countries. ${ }^{13}$ The immunological mechanism of this relation is yet controversial. The answer may lie in the model involving the TH1-TH2 dichotomy, when the exposition to helminthes favor a bigger $\mathrm{TH} 2$ stimulation, which is also observed in allergic diseases. ${ }^{26}$ This way, the presence of ascariasis shows a contrary effect in allergic diseases' severity.

Since a high prevalence of enteroparisitoses ${ }^{10}$ are observed in the area studied and all the children present a complete vaccination schedule, a decrease in allergic disease and the triggering of TH1 immune protective factors occurrence, working as a mechanism for lower $A D$ occurrence, would be expectable. ${ }^{14,27}$

The high prevalence of atopy in children's relatives was affirmed by Sebok et al., ${ }^{28}$ who associated allergic diseases to genetic heritage of father, mother, grandparents, and relatives. Therefore, family background is one of the most important factors for diagnosis and it expresses the patient's atopic constitution. In this study, atopy among mothers with rhinitis, and $A D$, and that of brothers, with $A D$ are related. Among them, the greater risk of the severe form of $A D$ in children was originated from the patient having a brother with $A D$, corroborating the idea of genetic predisposition. Mothers and brothers studied shared the same environment, so heredity could be assessed. Information gathering on the father was hindered, for most mothers assume responsibility for their children alone.

Data obtained in this study show that for 2 to 10 year-old children living in urban area with low socioeconomic indexes, infestation by $A$. lumbricoides could be a determining factor for a lower AD severity.

\section{Acknowledgements}

To Professor Dirceu Solé, Chair at Universidade de São Paulo - Escola Paulista de Medicina (UNIFESP-EPM), São Paulo, who, even distant, encouraged the ellaboration of this study. To Professor Ricardo A. Ximenes, Adjunct Professor, Health Sciences Center, Departamento de Medicina Tropical, Universidade Federal de Pernambuco (UFPE), Recife (PE), for the revision of the statistic study. 


\section{References}

1. Camelo-Nunes IC, Wandalsen GF, Melo KC, Naspitz CK, Sole D. Prevalence of atopic eczema and associated symptoms in school children. J Pediatr (Rio J). 2004;80:60-4.

2. Thestrup-Pedersen K. Clinical aspects of atopic dermatitis. Clin Exp Dermatol. 2000;25:535-43.

3. Strachan DP. Allergy and family size: a riddle worth solving. Clin Exp Allergy. 1997;27:235-6.

4. Anderson HR, Poloniecki JD, Strachan DP, Beasley R, Bjorksten $B$, Asher MI. Immunization and symptoms of atopic disease in children: results from the International Study of Asthma and Allergies in Childhood. Am J Public Health. 2001;91:1126-9.

5. Yamada E, Vanna AT, Naspitz CK, Solé D. International Study of Asthma and Allergies in Childhood (ISAAC): validation of the written questionnaire (eczema component) and prevalence of atopic eczema among Brazilian children. J Investig Allergol Clin Immunol. 2002;12:34-41.

6. Sole D, Wandalsen GF, Camelo-Nunes IC, Naspitz CK. Prevalence of symptoms of asthma, rhinitis, and atopic eczema among Brazilian children and adolescents identified by the International Study of Asthma and Allergies in Childhood (ISAAC) - Phase 3. J Pediatr (Rio J). 2006;82:341-6.

7. Wordemann M, Diaz RJ, Heredia LM, Collado Madurga AM, Ruiz Espinosa A, Prado RC, et al. Association of atopy, asthma, allergic rhinoconjunctivitis, atopic dermatitis and intestinal helminth infections in Cuban children. Trop Med Int Health. 2008; 13:180-6.

8. Flohr C, Tuyen LN, Lewis S, Quinnell R, Minh TT, Liem HT, et al. Poor sanitation and helminth infection protect against skin sensitization in Vietnamese children: A cross-sectional study. J Allergy Clin Immunol. 2006;118:1305-11.

9. Ferreira MU, Ferreira CS, Monteiro CA. Secular trends in intestinal parasitic diseases of childhood in the city of Sao Paulo, Brazil (1984-1996). Rev Saude Publica. 2000;34:73-82.

10. Nascimento Silva MT, Pontes A, Aragão P, Andrade J, Tavares-Neto J. Prevalência de parasitos intestinais em crianças, com baixos indicadores sócio-economicos em Campina Grande (Paraíba). Rev Bahiana Saúde Pública. 2005;29:121-5.

11. Scrivener S, Yemaneberhan $H$, Zebenigus M, Tilahun D, Girma $S$, Ali S, et al. Independent effects of intestinal parasite infection and domestic allergen exposure on risk of wheeze in Ethiopia: a nested case-control study. Lancet. 2001;358:1493-9.

12. Cooper PJ, Chico ME, Rodrigues LC, Ordonez M, Strachan D, Griffin $\mathrm{GE}$, et al. Reduced risk of atopy among school-age children infected with geohelminth parasites in a rural area of the tropics. J Allergy Clin Immunol. 2003;111:995-1000.

13. Dagoye D, Bekele Z, Woldemichael K, Nida H, Yimam M, Hall A, et al. Wheezing, allergy, and parasite infection in children in urban and rural Ethiopia. Am J Respir Crit Care Med. 2003;167:1369-73.

14. Lynch NR, Hagel IA, Palenque ME, Di Prisco MC, Escudero JE, Corao LA, et al. Relationship between helminthic infection and IgE response in atopic and nonatopic children in a tropical environment. J Allergy Clin Immunol. 1998;101:217-21.

15. Williams $\mathrm{H}$, Flohr $\mathrm{C}$. How epidemiology has challenged 3 prevailing concepts about atopic dermatitis. J Allergy Clin Immunol. 2006;118:209-13.
16. Leonardi-Bee J, Pritchard D, Britton J. Asthma and current intestinal parasite infection: systematic review and meta-analysis. Am J Respir Crit Care Med. 2006;174:514-23.

17. Medeiros M, Carvalho EM, Araújo MI. Schistosoma mansoni infection, allergy, and asthma. Allergy Clin Immunol Int. 2005;17:220-3.

18. Nascimento Silva MT. Prevalência de ascaridíase e asma no bairro do Pedregal da cidade de Campina Grande [dissertação]. Campina Grande: Universidade Federal da Bahia, Universidade Federal da Paraíba; 2002.

19. Instituto Brasileiro de Geografia e Estatística (IBGE). Censo demográfico 2000. Rio de Janeiro: IBGE; 2002.

20. Wuthrich B, Baumann E, Fries RA, Schnyder UW. Total and specific IgE (RAST) in atopic twins. Clin Allergy. 1981;11:147-54.

21. Nascimento Silva MT, Andrade J, Tavares-Neto J. Asthma and ascariasis in children aged two to ten living in a low income suburb. J Pediatr (Rio J). 2003;79:227-32.

22. Weiland SK, Husing A, Strachan DP, Rzehak P, Pearce N; ISAAC Phase One Study Group. Climate and the prevalence of symptoms of asthma, allergic rhinitis, and atopic eczema in children. Occup Environ Med. 2004;61:609-15.

23. Solé D, Camelo-Nunes IC, Wandalsen GF, Mallozi MC, Naspitz CK. Prevalence of atopic eczema and related symptoms in Brazilian schoolchildren: results from the International Study of Asthma and Allergies in Childhood (ISAAC) phase 3. J Investig Allergol Clin Immunol. 2006;16:367-76.

24. Nnoruka EN. Current epidemiology of atopic dermatitis in southeastern Nigeria. Int J Dermatol. 2004;43:739-44.

25. Martin Fernández-Mayoralas D, Martin Caballero JM, Garcia-Marcos Alvarez L. Prevalencia de la dermatitis atópica en escolares de Catagena y su relación con el sexo y la contaminación. An Pediatr (Barc). 2004;60:555-60.

26. SchäferT, MeyerT, Ring J, Wichmann HE, Heinrich J. Worm infestation and the negative association with eczema (atopic/nonatopic) and allergic sensitization. Allergy. 2005;60:1014-20.

27. Cooper PJ. Intestinal worms and human allergy. Parasite Immunol. 2004;26:455-67.

28. Sebok B, Schneider I, Harangi F. Familiar and environmental factors influencing atopic dermatitis in the childhood. J Eur Acad Dermatol Venereol. 2006;20:418-22.

\section{Correspondence:}

Maria Teresa Nascimento Silva

Rua José Augusto Ribeiro, 115 apto. 601, Bela Vista.

CEP 58428-720 - Campina Grande, PB - Brazil

Tel. : +55 (83) 3333.1976, +55 (83) 3322.3020

+55 (83) 9971.3446

Fax: +55 (83) 3333.1976, +55 (83) 3322.3020

E-mail: teresans@terra.com.br 